\title{
Tax Incentives in Indonesia during the COVID-19 Pandemic
}

\author{
Ernie*, Marcelino** $^{* *}$ \\ * Institut Ilmu Sosial dan Manajemen, Sekolah Tinggi Ilmu Administrasi Mandala Indonesia (STIAMI) \\ *** Institut Ilmu Sosial dan Manajemen, Sekolah Tinggi Ilmu Administrasi Mandala Indonesia (STIAMI) \\ DOI: 10.29322/IJSRP.11.05.2021.p11341 \\ http://dx.doi.org/10.29322/IJSRP.11.05.2021.p11341
}

\begin{abstract}
Tax incentives for taxpayers in Indonesia when the COVID-19 pandemic outbreak, which are expected to have a positive impact on the business world and prevent Indonesia from being in a recession, are interesting to research. The problem formulated in this research was how effective are the new tax incentives for taxpayers in Indonesia, either personal taxpayers or company taxpayers except permanent establishment, in the COVID-19 pandemic era. This paper used a qualitative method approach with literature study as the research methodology. The data were collected from various pieces of literature in the forms of documents, journals, statutory regulations, official news, and government publication data relevant to the research. The data analysis was done by collecting data, reducing data, presenting data, and drawing conclusions. The results indicated that tax incentives in Indonesia are effective in managing financial problems during the pandemic.
\end{abstract}

Index Terms-Tax Incentives, The COVID-19 Pandemic, Income Tax, Business World

\section{INTRODUCTION}

$\mathrm{T}$ The world was shocked by the emergence of the new virus named SARS-CoV-02 virus which led to the Corona Virus Disease 2019 (COVID-19) in the beginning of 2019 (Cahyati and Kusumah, 2020). Covid-19 has been infecting throughout many countries and officially announced to become a global pandemic disease by World Health Organization (World Health Organization, 2020). In addition to the country's health impact, the economic activities of all countries, including Indonesia, received an unavoidable threat of an economic recession (Fiscal Policy Agency, 2020).

Data from the Central Statistics Agency of Indonesia (2020) shows that the country's economic growth in Q-4 2019 was 4.97\%, Q-1 2020 was $2.97 \%$, and Q-2 2020 was -5.32\%. The contraction within Q-1 and Q-2 2020 was due to negative growth in all components of expenditure, which result to the beginning of Indonesia recession.

The COVID-19 pandemic has also affected state tax revenues due to weaker economic conditions. Besides, non-tax state revenue has also experienced a decline, marked by falling commodities and decreasing purchasing power. These showed that various economic activities in the country decreased, resulting in the business world being severely hit (Aulawi, 2020).

In order to manage the impact of COVID-19 and/or to prevent threats that can interrupt the national economy growth, the government released Peraturan Pemerintah Pengganti Undang-Undang (Perppu) nomor 1 tahun 2020 regarding the country financial policies and system. The Government Regulation in Lieu of Law in question was then promulgated as Law Number 2 of 2020, aiming to protect the community in the aspects of health, social life, and community economy, and also for financial sector during the pandemic (Ministry of Finance, 2020).

The releasing of Perpu No. 1 year 2020 was followed by derivative regulation, namely Peraturan Menteri Keuangan (PMK) nomor 23 tahun 2020 (PMK 23/PMK.03/2020). But the derivative regulation was changed twice into PMK Number 44/PMK.03/2020 and PMK Number 86/PMK.03/2020. This regulation stating about tax incentives for taxpayers in Indonesia that were affected by the Covid-19 outbreak. There are several tax incentives that are mentioned, namely Governemnt Article 21 borne Income Tax, Final Income Tax based on Peraturan Pemerintah Number 23 of 2018, Article 22 Income Tax concerning Imports, Article 25 concerning Income Tax Installments, and VAT.

Previously before pandemic, the tax rate followed the normal situation, namely Article 21 Income Tax of 5\% if the annual taxable income reaches up to 50 million rupiahs, $15 \%$ if the annual taxable income reaches above 50 million rupiahs to 250 million rupiahs, $25 \%$ if the annual taxable income reaches above 250 million rupiahs to 500 million rupiahs, and $30 \%$ if the annual taxable income reaches more than 500 million rupiahs. And Income Tax Article 22 was $1.5 \%$ of the purchase price which did not include value-added tax and was also not final.

Income Tax Article 25 regarding tax installments are also divided into two types of payments. Personal taxpayers of certain entrepreneurs, are calculated with tax rate of $0.75 \%$ of the revenue of every business place monthly, and individual taxpayers other than certain entrepreneurs, are calculated with tax rate of $25 \%$ from taxable income. Regarding VAT, the process of VAT restitution is becoming more convenience, and final income tax for UMKM, which were calculated with the rate of $0.5 \%$ from gross revenue. 
Based on the above explanation, the Indonesian government has been continuing to promote policies that can have a positive impact on the business world and also trying to prevent Indonesia from entering into a recession. Researchers were interested in researching tax incentives for Indonesian taxpayers during the COVID-19 pandemic. The research question in this study is "has the tax incentives been effective during the COVID-19 pandemic?" The purpose of this study was to determine the effectiveness of those tax incentives.

\section{RESEARCH METHOD}

In this study, research identification on previous research, research methods, and research data collection needed to be done first. Previous research that supported this research included those conducted by Aulawi (2020), Kumala and Junaidi (2020), and Suharti et al. (2020). Aulawi's research results (2020) showed that the policy of issuing Perppu number 1 of year 2020 and tax relaxation was effective in overcoming the problems of state finances and the unstable economy in the COVID-19 pandemic. Meanwhile, Kumala and Junaidi's research results (2020) stated that UMKM appreciated the tax incentive policy contained in the Peraturan Pemerintah, applied these tax incentives and continued to improve tax compliance. Suharti et al. (2020) concluded that tax incentives had significant positive effect to prevent Indonesia from economic crisis. From the three previous studies, it could be said that tax incentives were effective in overcoming the problems faced by the business world and economic problems during the pandemic.

Secondly, in this study, the researchers used a qualitative research approach, which explore the relationship and description of the materiality by gathering and analysing qualitative data (Saraclaers, 1993). The researchers used a literature study methodology and gathering data by finding, learning, and analysing from numerous literatures in the forms of documents, journals, laws and regulations, and official news or government publication data whose information was relevant to the research. Data analysis was carried out by collecting data, reducing data, presenting data, and drawing conclusions.

\section{FINDINGS AND DISCUSSION}

Government policy during the pandemic has been regulated in Perppu number 1 of 2020 to save the national economy by focusing on health spending, social safety net, and economic recovery, including for businesses which are directly impacted from the pandemic. Perppu Number 1 of 2020 places more emphasis on national economic recovery which also regulates tax policies during the Corona Virus pandemic. The tax policy mentions about changes in income tax rates during the pandemic, enactment of digital taxes for commerce via electronic systems, and time extension to fulfill tax fillings.

The first taxation policy includes the income tax rate modification for domestic taxpayers and permanent business entities that was previously 28\% in Law Number 36 of 2008 in Article 17 Paragraph (1) and replaced into 22\% in the fiscal year of 2020 and 2021, and lastly replaced to $20 \%$ in the fiscal year of 2022 . The second tax policy is, in addition to tax rate adjustments in tax policies in Perppu Number 1 of 2020, the tax treatment on commerce via electronic systems, where these trading will be imposed to tax in the forms of digital VAT and income tax.

Based on the above explanation, it is reflected that the government is carrying out tax reforms among uncertainty caused by the negative implication during the pandemic, by paying attention to and supporting the business world to accelerate national economic recovery. The first tax reform is to provide tax relaxation to the business world, which is to reduce the burden on business activities by reducing and exempting taxes to minimize price increases and termination of employment for employees. Also, both reduction of company income tax and import tax and import duty exemption for particular business sectors are intended to increase economic and investment activities so that they can grow a positive impact on the country overall economy. These are shown in Figure 3.1 as follows:

Figure 3.1. Tax Reform in 2020

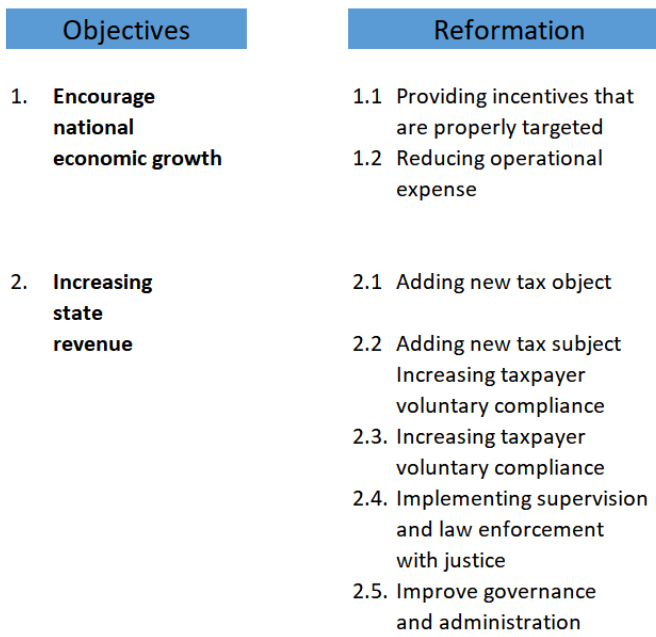

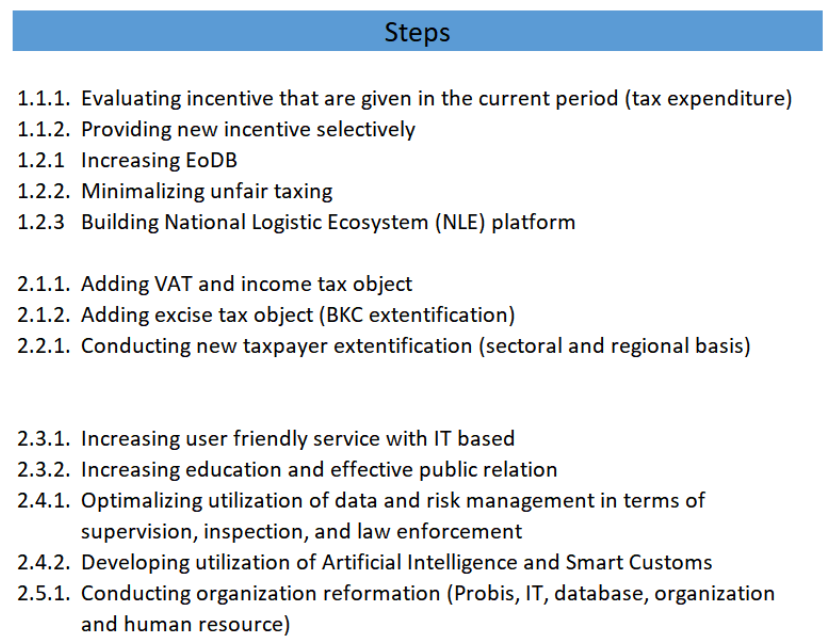

This publication is licensed under Creative Commons Attribution CC BY. 
Source: Indonesia Ministry of Finance (2020)

The third tax policy is to extend the time to exercise rights and fulfill obligations in terms of taxation. Taxpayers can file an objection to get an extension of time, namely 6 months, and can apply for a reduction and abolition of tax administration sanctions, which remain a maximum of 6 months. After the emergence of Perppu Number 1 of 2020, it is followed by a derivative regulation, namely the PMK Number 23 of 2020.

Because PMK Number 23 of 2020 was still insufficient in scope regarding the code of business fields that receive incentives, a new regulation emerged to replace it, namely the PMK Number 44 of 2020, where this regulation aims to widen the business industries, so that more industries can take advantage of the tax incentives that are provided. Meanwhile, over time, the period given was only 6 months, so a new regulation was made, namely Regulation of the Minister of Finance Number 86/PMK.03/2020 with a period until the end of 2020.

The Indonesian government continued to strive to save the economy and responded to the decline in productivity from business activities because business activities or business actors had been severely hit by the negative impact from the pandemic. Therefore, in PMK Number 44 of 2020, the government will be borne the final tax which calculated from PMK 23 of 2020.

PMK Number 23/PMK.03/2020 has stated 4 fiscal incentives, while PMK Number 44/PMK.03/2020 only stated 1 fiscal incentive. The total will be 5 fiscal incentives, which were:

1. "Article 21 Income Tax Incentive, where the tax incentive is $100 \%$ borne by the government; the worker specifications should be following the established business field codes and the income is not more than 200 million rupiahs per year. The purpose of this Article 21 Income Tax Incentive is that workers who comply with the business field code (manufacturing companies) can receive additional income and maintain purchasing power."

2. "Article 22 Income Tax Incentive on Imports. This tax incentive facilitates 19 manufacturing industry sectors, both at the location of import convenience for export destinations (KITE) and non-KITE. The incentive is given in the form of an Article 22 Import Income Tax exemption scheme for the 19 special sectors in the manufacturing industry because previously there were restrictions between countries that required the closure of the inflow of goods."

3. "Article 25 Income Tax Installment Incentive will be the provision of tax reduction scheme that is raging from $30 \%$ to $50 \%$ for specific sector from 19 manufacturing industry that are suitable for KITE and non-KITE."

4. "Value-added tax incentive, which enables more convenience in the process of granting VAT restitution. If the entrepreneur is an exporter, then there is no nominal limit on the VAT refund, but if the entrepreneur is a non-exporter, the maximum restitution nominal is 5 billion rupiahs."

5. "Final income tax incentive for UMKM, which is a final income tax with the tax rate of $0.5 \%$ from revenue and will not be imposed to entrepreneur, but will be borne by the government."

For those five incentives, the activeness period was only from April to September 2020. PMK Number 86/PMK.03/2020 was issued in order to give time extension, which extending it to December 2020. The five fiscal incentives were included in one of the six main focuses of the government in the national economic recovery program (NERP), as shown in Figure 3.1 below:

Figure 3.1. National Economic Recovery Program (NERP)

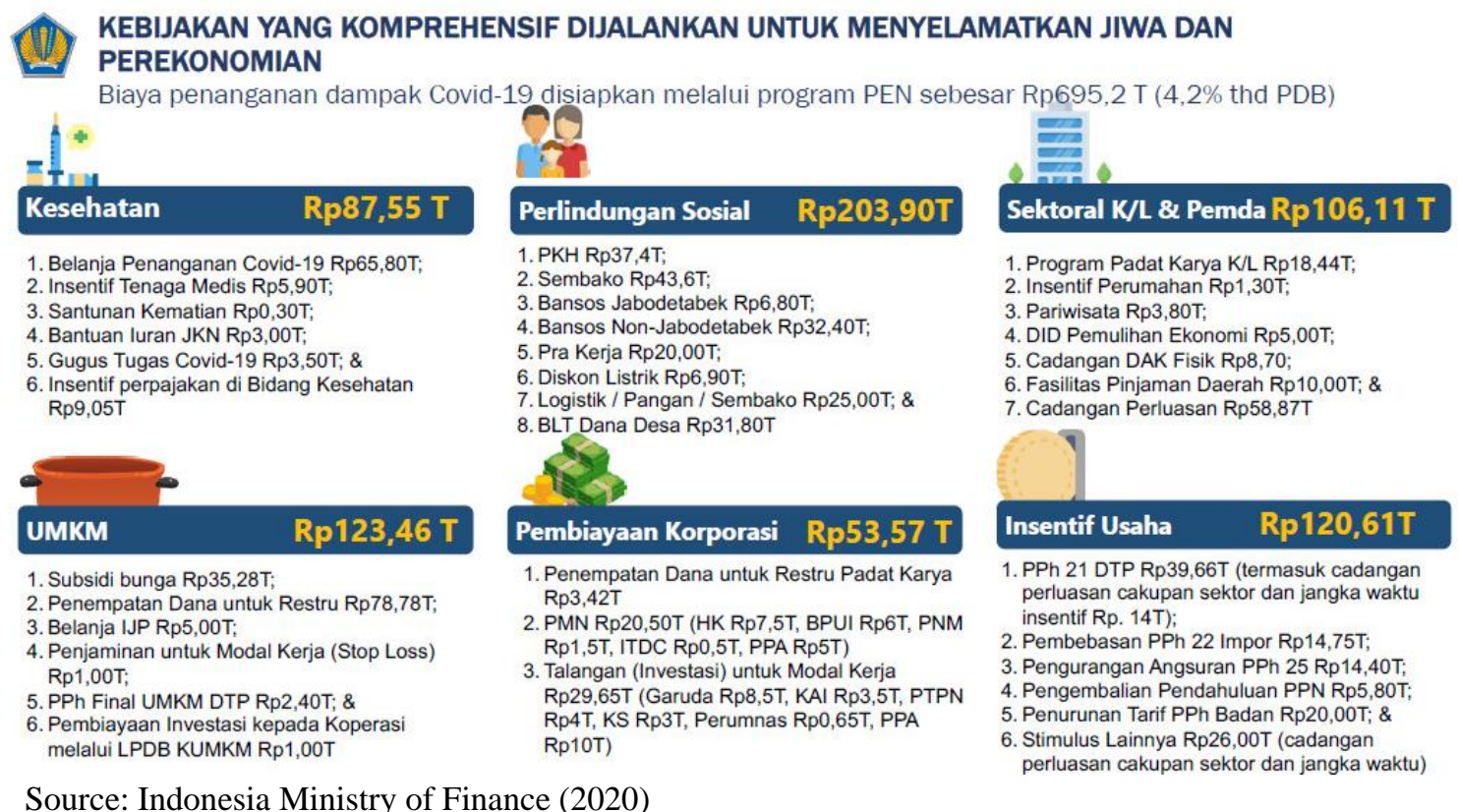

This publication is licensed under Creative Commons Attribution CC BY.

http://dx.doi.org/10.29322/IJSRP.11.05.2021.p11341

WwW.ijsrp.org 
The five Incentives contained in the PMK provided by the government through the NERP has a budget that totals to IDR 120.61 Trillion which are distributed as follows:

1. Article 21 Income Tax is IDR 39.66 trillion, along with reserves for expansion of sector coverage and a period of incentive provision of IDR 14 trillion.

2. Article 22 Import Income Tax Exemption amounting to IDR 14.75 trillion.

3. Article 25 Tax Installment amounting to IDR14.40 trillion.

4. Accelerated VAT refund of IDR 5.80 trillion.

5. Final income tax for UMKM, which is IDR 2.40 trillion.

These were supported by the PMK Number 185/PMK.03/2020, Article 6 Paragraph (4) of which states that the handling of the COVID-19 pandemic contained in the NERP through tax expenditure includes:

1. Changes in tax rate of income tax for both domestic company taxpayers and for permanent business.

2. Tax treatment in trading activities through electronic systems.

3. Time extension fulfill tax rebate form.

4. Authorization to the Ministry to facilitate customs facilities.

Meanwhile, in relation to tax incentives, Figure 3.2 shows the development of tax revenue in 2020 as follows:

Figure 3.2. State Tax Revenue in 2020

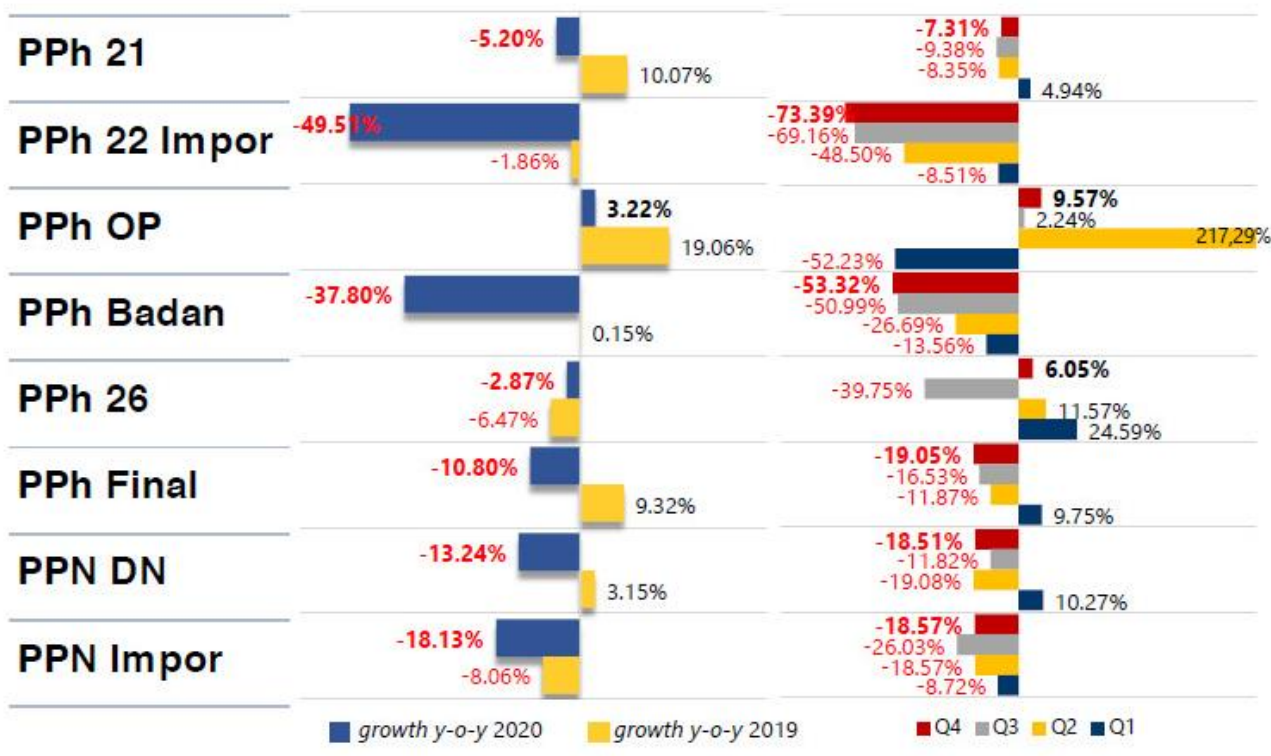

Source: Indonesia Ministry of Finance (2020)

Several types of taxes improved in Q-4 of 2020, including Article 21 income tax, Article 22 income tax, personal income tax, corporate income tax, Article 26 income tax, final income tax, domestic value-added tax, and value-added tax of imports coincided with economic recovery, although it can still be said to be in the negative zone. The tax revenue experiencing positive growth was personal income tax, both year-on-year growth in 2019 and 2020 and Q-1 to Q-4 of 2020.

Based on the NERP and state tax revenue above, it is necessary to see the 2020 tax revenue realization as shown in Figure 3.3 below: 
Figure 3.3. Realization of Tax Revenues in 2020

\begin{tabular}{|c|c|c|c|c|c|c|}
\hline \multirow{2}{*}{$\begin{array}{l}\text { Uraian } \\
\text { (triliun rupiah) }\end{array}$} & \multirow{2}{*}{$\begin{array}{l}2019 \\
\text { Realisasi }\end{array}$} & \multirow[b]{2}{*}{ APBN } & \multicolumn{3}{|c|}{2020} & \multirow[b]{2}{*}{$\begin{array}{l}\text { Growth } \\
(\%)\end{array}$} \\
\hline & & & $\begin{array}{l}\text { Perpres } \\
72 / 2020\end{array}$ & $\begin{array}{l}\text { Realisasi } \\
\text { Sementara }\end{array}$ & $\begin{array}{l}\% \text { thd } \\
\text { Perpres } \\
72 / 2020\end{array}$ & \\
\hline A. Penerimaan Pajak & $1.332,7$ & $1.642,6$ & $1.198,8$ & $1.070,0$ & 89,3 & $(19,7)$ \\
\hline 1. PPh Migas & 59,2 & 57,4 & 31,9 & 33,2 & 104,1 & $(43,9)$ \\
\hline 2. Pajak Nonmigas & $1.273,5$ & $1.585,1$ & $1.167,0$ & $1.036,8$ & 88,8 & $(18,6)$ \\
\hline a. PPh Non Migas & 713,1 & 872,5 & 638,5 & 560,7 & 87,8 & $(21,4)$ \\
\hline b. Pajak Pertambahan Nilai & 531,6 & 685,9 & 507,5 & 448,4 & 88,4 & $(15,6)$ \\
\hline c. Pajak Bumi dan Bangunan & 21,1 & 18,9 & 13,4 & 21,0 & 155,9 & $(0,9)$ \\
\hline d. Pajak Lainnya & 7,7 & 7,9 & 7,5 & 6,8 & 90,6 & $(11,7)$ \\
\hline B. Kepabeanan dan Cukai & 213,5 & 223,1 & 205,7 & 212,8 & 103,5 & $(0,3)$ \\
\hline 1. Cukai & 172,4 & 180,5 & 172,2 & 176,3 & 102,4 & 2,3 \\
\hline 2. Pajak Perdagangan Internasional & 41,1 & 42,6 & 33,5 & 36,5 & 108,9 & $(11,1)$ \\
\hline a. Bea masuk & 37,5 & 40,0 & 31,8 & 32,3 & 101,3 & $(14,0)$ \\
\hline b. Bea keluar & 3,5 & 2,6 & 1,7 & 4,2 & 255,0 & 19,5 \\
\hline TOTAL & $1.546,1$ & $1.865,7$ & $1.404,5$ & $1.282,8$ & 91,3 & $(17,0)$ \\
\hline
\end{tabular}

Source: Indonesia Ministry of Finance (2020)

The total of tax revenue realization during 2020 is amounting to IDR 1,282.8 trillion, this amount is almost reaching the government target, which now already fulfill $91.3 \%$. Therefore, it can be concluded that the tax revenue realization already recovered in the fourth quarter of 2020, even though it was still a negative. Economic conditions would also be able to recover from pandemic since the tax revenue was still growing into better direction.

Tax revenue in Figure 3.2 and its realization in Figure 3.3 above is again strengthened by the implementation of the 2020 State Revenue and Expenditure Budget which is shown in Figure 3.4 as follows:

Figure 3.4. Implementation of the State Revenue and Expenditure Budget of 2020

PELAKSANAAN APBN 2020 FOKUS PADA PENANGANAN KESEHATAN DAN DAMPAK COVID-19 TERHADAP MASYARAKAT DAN DUNIA USAHA

APBN bekerja keras untuk rakyat agar dapat bangkit kembali dan menuju pada pemulihan ekonomi

\begin{tabular}{|c|c|c|c|c|c|c|}
\hline \multirow[b]{2}{*}{$\begin{array}{c}\text { Uraian } \\
\text { (triliun rupiah) }\end{array}$} & \multirow{2}{*}{$\begin{array}{l}2019 \\
\text { Realisasi }\end{array}$} & \multirow[b]{2}{*}{ APBN } & \multicolumn{3}{|c|}{2020} & \multirow[b]{2}{*}{$\begin{array}{l}\text { Growth } \\
(\%)\end{array}$} \\
\hline & & & $\begin{array}{l}\text { Perpres } \\
72 / 2020\end{array}$ & $\begin{array}{l}\text { Realisasi } \\
\text { Sementara }\end{array}$ & $\begin{array}{l}\text { \% thd } \\
\text { Perpres } \\
72 / 2020\end{array}$ & \\
\hline A. PENDAPATAN NEGARA & $1.960,6$ & $2.233,2$ & $1.699,9$ & $1.633,6$ & 96,1 & $(16,7)$ \\
\hline 1. Penerimaan Pajak & $1.332,7$ & $1.642,6$ & $1.198,8$ & $1.070,0$ & 89,3 & $(19,7)$ \\
\hline II. Kepabeanan \& Cukai & 213,5 & 223,1 & 205,7 & 212,8 & 103,5 & $(0,3)$ \\
\hline III. PNBP & 409,0 & 367,0 & 294,1 & 338,5 & 115,1 & $(17,2)$ \\
\hline IV. Hibah & 5,5 & 0,5 & 1,3 & 12,3 & 945,8 & 123,7 \\
\hline B. BELANJA NEGARA & $2.309,3$ & $2.540,4$ & $2.739,2$ & $2.589,9$ & 94,6 & 12,2 \\
\hline I. BPP & $1.496,3$ & $1.683,5$ & $1.975,2$ & $1.827,4$ & 92,5 & 22,1 \\
\hline 1. Belanja K/L & 873,4 & 909,6 & 836,4 & $1.055,0$ & 126,1 & 20,8 \\
\hline 2. Belanja Non $\mathrm{K} / \mathrm{L}$ & 622,9 & 773,9 & $1.138,9$ & 772,3 & 67,8 & 24,0 \\
\hline a.l a. Pembayaran Bunga Uta ig & 275,5 & 295,2 & 338,8 & 314,1 & 92,7 & 14,0 \\
\hline b. Subsidi & 201,8 & 187,6 & 192,0 & 196,2 & 102,2 & $(2,8)$ \\
\hline II. TKDD & 813,0 & 856,9 & 763,9 & 762,5 & 99,8 & $(6,2)$ \\
\hline 1. Transfer ke Daerah & 743,2 & 784,9 & 692,7 & 691,4 & 99,8 & $(7,0)$ \\
\hline 2. Dana Desa & 69,8 & 72,0 & 71,2 & 71,1 & 99,9 & 1,8 \\
\hline C. KESEIMBANGAN PRIMER & $(73,1)$ & $(12,0)$ & $(700,4)$ & $(642,2)$ & 91,7 & 778,1 \\
\hline D. SURPLUS/(DEFISIT) & $(348,7)$ & $(307,2)$ & $(1.039,2)$ & $(956,3)$ & 92,0 & 174,3 \\
\hline$\%$ thd PDB & $(2,20)$ & $(1,76)$ & $(6,34)$ & $(6,09)$ & & \\
\hline E. PEMBIAYAAN ANGGARAN & 402,1 & 307,2 & $1.039,2$ & $1.190,9$ & 114,6 & 196,2 \\
\hline SiLPAV(SiKPA) & 53,4 & - & -1 & 234,7 & & \\
\hline
\end{tabular}

1. Realisasi Pendapatan Negara tahun 2020 sebesar Rp1.633,6 T lebih rendah Rp327 T dari tahun 2019 atau lebih rendah Rp599,6 T dari target APBN 2020.

2. Realisasi Penerimaan perpajakan lebih rendah sebagai dampak perlambatan ekonomi dan pemanfaatan stimulus perpajakan oleh dunia usaha. Kepabeanan \& Cukai relatif lebih baik didukung kebijakan tarif cukai dan pengendalian rokok ilegal. Realisasi PNBP melebihi target ditopang oleh harga komoditas yang membaik di akhir tahun 2020.

3. Belanja Negara naik $12,2 \%$ dari realisasi 2019 yang didukung oleh kebijakan refocusing/realokasi belanja K/L dan TKDD yang diarahkan untuk mendukung penanganan Covid-19 dan dampaknya terhadap masyarakat dan dunia usaha sebesar Rp579,8 T (Program PEN).

4. Realisasi program PEN sangat nyata membantu penanganan Covid-19 dan dampaknya terhadap masyarakat dan dunia usaha.

5. Defisit dapat dikendalikan lebih rendah Rp82,9 T dari Rp1.039,2 T menjadi Rp956,3 T

6. Terdapat Silpa Rp234,7 T yang didalamnya termasuk Rp66,75 T untuk dukungan dunia usaha melalui perbankan, serta Rp50,9 T akan di-carryover untuk penanganan kesehatan dan PEN lainnya di tahun $2021 . \quad j s r p . o r g$ 
Source: Indonesia Ministry of Finance (2020)

In Figure 3.4, the 2020 state expenditure increased by 12.2\% from 2019's realization, aiming to support the handling of COVID19 and its impact on society and the business world through NERP of IDR 578.8 trillion. In this regard, it can be concluded that the realization of the NERP, containing business incentives, was indeed effective and significantly helpful. It was also proven that in Q-2 2020 economic growth against Q-3 2020, namely in Q-2 2020, Indonesia's economic growth contracted until falling to -5.32\%, and in Q-3 2020 experienced an increase by $1.83 \%$ to be $-3.49 \%$. Thus, tax incentives in Indonesia are considered effective in dealing with the impact of the COVID-19.

These findings were also supported by the results of research by Aulawi (2020) stating that tax relaxation is effective in overcoming unstable state finances and economic problems due to the COVID-19, namely with other tax policies such as tax rate adjustments, the treatment of trade tax through electronic systems, extension of the exercise of rights and fulfillment of tax obligations. These were confirming the results of research by Kumala and Junaidi (2020), stating that UMKM appreciated the tax incentive policy contained in the Peraturan Pemerintah, applied these tax incentives and continued to improve tax compliance.

The results of this study were also supported by the results of research by Suharti et al. (2020) that showed that tax incentives had significant positive effect to prevent Indonesia from economic crisis. Furthermore, the results were also in accordance to the the results of another research by Sopanah and Haikal (2021) that represented the NERP, which contains of 6 main focuses, namely health, social protection, sectoral ministries/institutions and local governments, UMKM, corporate financing, and business incentives, is supported by budget refocusing by the government.

This study had implications and limitations. The implications of the research results included both theoretical and practical sides. Theoritically, the results of this study could explore the concept of Indonesia fiscal incentives during the COVID-19 pandemic, especially regarding its effectiveness, and as reference material for future researchers. Practically, the result of this study could become an insight for Indonesian government about overcoming economic problems due to pandemic. The limitation of this study was that it used a literature study, where the data source gathered was minimum and then presented to produce a general conclusion regarding Indonesia tax incentives during the pandemic COVID-19.

\section{CONCLUSION}

The research results showed that Indonesian tax incentives during the pandemic COVID-19, looked from the realization of the state revenue and expenditure budget in which there are business incentives, are indeed very effective and very real helping with their impact on the business world, including the incentive for Article 21 income tax borne by the government, the exemption of Article 22, the reduction of Article 25, accelerated VAT restitution process, and final income tax for UMKM that are borne by the government.

Furthermore, the researchers provide suggestions or recommendations as follows:

1. Because tax incentives change at any time and tax incentives also exist when under certain conditions, further researchers who are interested in researching tax incentives must first understand the contents of tax incentives and the purpose of these tax incentives.

2. The next researchers who are interested in researching Indonesia tax incentives during pandemic can explore other research materials that are still related to tax incentives by using either qualitative or quantitative research approaches to provide benefits to stakeholders.

\section{REFERENCES}

[1] A. Aulawi, "Penerbitan Peraturan Pemerintah Pengganti Undang-Undang Nomor 1 Tahun 2020 sebagai Strategi Kebijakan Pajak Pemerintah Indonesia dalam Menghadapi Dampak Pandemi Covid-19 Terhadap Keuangan Negara", Jurnal Pendidikan, Akuntansi dan Keuangan, vol. 3, no. 2. pp. 110-132.

[2] Badan Kebijakan Fiskal, Kerangka Ekonomi Makro dan Pokok-pokok Kebijakan Fiskal Tahun 2021: Percepatan Pemulihan Ekonomi dan Penguatan Reformasi, Jakarta, Indonesia: Badan Kebijakan Fiskal Kementerian Keuangan Republik Indonesia, 2020, pp. 1-230.

[3] Badan Pusat Statistik, Pertumbuhan Ekonomi Indonesia Triwulan III-2020, Jakarta, Indonesia: BPS Pusat, 2020, pp. 1-12.

[4] Kementerian Keuangan Republik Indonesia, "UU No. 2 Tahun 2020 Bukti Negara Hadir Berikan Perlindungan Terhadap Dampak Covid-19". Melalui "https://www.kemenkeu.go.id/publikasi/berita/uu-no-2-tahun-2020-bukti-negara-hadir-berikanperlindungan-terhadap-dampak-covid-19/"

[5] N. Cahyati dan R. Kusumah, "Peran Orang Tua dalam Menerapkan Pembelajaran di Rumah Saat Pandemi COVID-19", Jurnal Golden Age, vol. 3, no. 1. pp. 152-159.

This publication is licensed under Creative Commons Attribution CC BY.

http://dx.doi.org/10.29322/IJSRP.11.05.2021.p11341

WWW.ijsrp.org 
[6] World Health Organization, "WHO Coronavirus Disease 2019 (COVID-19) Dashboard". Melalui https://covid-19.who.int/

[7] R. Kumala dan A. Junaidi, "Strategi Bisnis dan Pemanfaatan Kebijakan Pajak di Masa Pandemi COVID-19 dan Era New Normal (Studi Kasus Pelaku UKM Marketplace)”, Prosiding Seminar STIAMI, vol. 7, no. 2. pp. 98-103.

[8] E. Suharti, S. Chanifah, R. T. Amanda, "Pencegahan Krisis Melalui Pemanfaatan Insentif Pajak dan Penerapan Lean Manufacturing”, Prosiding Konferensi Nasional Ekonomi Manajemen dan Akuntansi (KNEMA), vol. 1, no. 1. pp. 1-13.

[9] Saraclaers, Social Research, Australia: MacMillan Education, 1993.

[10] "Peraturan Pemerintah Pengganti Undang-Undang Nomor 1 Tahun 2020, Penetapan Peraturan Pemerintah Pengganti UndangUndang Nomor 1 Tahun 2020 tentang Kebijakan Keuangan Negara dan Stabilitas Sistem Keuangan untuk Penanganan Pandemi Corona Virus Disease 2019 (COVID-19) dan/atau dalam rangka menghadapi ancaman yang membahayakan Perekonomian Nasional dan/atau Stabilitas Sistem Keuangan”. 31 Maret 2020. Lembaran Negara Republik Indonesia Tahun 2020 Nomor 87. Jakarta.

[11] "Peraturan Menteri Keuangan Republik Indonesia Nomor 23/PMK.03/2020. Insentif Pajak untuk Wajib Pajak Terdampak Wabah Virus Corona". 23 Maret 2020. Berita Negara Republik Indonesia Tahun 2020 Nomor 277. Jakarta.

[12] "Peraturan Menteri Keuangan Republik Indonesia Nomor 44/PMK.03/2020. Insentif Pajak untuk Wajib Pajak Terdampak Pandemi Corona Virus Disease 2019”. 27 April 2020. Berita Negara Republik Indonesia Tahun 2020 Nomor 411. Jakarta.

[13] "Peraturan Menteri Keuangan Republik Indonesia Nomor 86/PMK.03/2020. Insentif Pajak untuk Wajib Pajak Terdampak Pandemi Corona Virus Disease 2019”. 16 Juli 2020. Berita Negara Republik Indonesia Tahun 2020 Nomor 781. Jakarta. 